\title{
INTERDEPENDENCE AND PEACE: PSYCHOLOGICAL EXPERIMENTAL APPROACH IN MULTICULTURE
}

\author{
Cholichul Hadi \\ Faculty of Psychology, Airlangga University-Surabaya, Indonesia. \\ Darmawangsa Selatan Street, Surabaya, East Java, Indonesia \\ Tel: (62)-31-5032-770 Fax: (62)-31-5025910 \\ cholichul_ririn@unair.ac.id \\ Ismail Suardi Wekke \\ Ford Foundation International Fellowship Program \\ Faculty of Education, Universiti Kebangsaan Malaysia \\ No. 8-2A, Jl. Hentian 5, Pusat Hentian Kajang, Selangor, D.E. \\ E-mail: iswekke@ antarbangsa.net \\ Cellphone: +60-16-240-2389 Fax. +60-3-8736-7334
} Paper Presented at the Tenth International Symposium on the Contributions of to Peace ,SoloUMS,
Yogyakarta UGM, on June 17-24, 2007

\begin{abstract}
AIM OF THE PAPER:: Positive interdependence has numerous effects on individuals' motivation and productivity group multicultural, not the least of which is to highlight the fact that the efforts of all group members multicultural are needed for group success as a nation building. When members of a group see their efforts as dispensable for the group's success, they may reduce their efforts. If the highest score in the group determined the group grade, for example, low-ability members might see their efforts as unnecessary and contribute minimally, and high ability members might feel exploited and become demoralized and, therefore, decrease their efforts so as not to provide undeserved rewards for irresponsible and ungrateful "free-riders". The samples studied included worker and student in suburban, village and city multicultural condition. The results indicated that Positive interdependence exists when one perceives that one is linked with others in a way so that one cannot succeed unless they do (and vice versa) and/or that one must coordinate one's efforts with the efforts of others to complete a task. HIPOTHESIS: Based on theoretical review, and previous findings it could be hypothesized that the positive interdependence could improve peace group performance. Positive Interdependence and Peace Group Performance is positive in Psychological Perpective. Multicultural education is a structured process designed to foster understanding, acceptance, and constructive relations among people of many different cultures. Ideally, it encourages people to see different cultures as a source of learning to respect diversity in the local, national, and international environment. It stresses cultural, ethnic, racial, and linguistic differences, and includes socio-economic differences (urban, rural, age/youth, worker/middle class), sex and religious differences, and awareness of one's own cultural heritage, and understanding that no one culture is intrinsically superior to another; secondly, to acquiring those skills in analysis and communication that help one function effectively in multicultural environments. Stress Is place on experiencing cultural differences in the classroom and in society, rather than simply studying about them. Multicultural education is not just a set of ethnic or other area study programs, but an effort to demonstrate the significance of similarities and differences among culture groups and between individuals within those groups. METHOD:The sampling technique that was used in this research was multistage sampling. The questionnaires were administrated. The questionnaires were distributed through the first harvest during the season. All of the items after try out were valid. The real experiment were conducted in the second The subjects of the experiments were 402 in Pemerintah Kota Surabaya. FINDING : The positive interdependence could improve peace group performance was the best, special in psychological perspective. (1) Based on theoretical review, and
\end{abstract}


previous findings it could be hypothesized that positive interdependencel function could improve social group, specially in social group. Moral action is the component of moral agency which brings knowing and affect to fruition. Moral action has three components: will, competence, and habit. Will is what mobilizes our moral energy--the energy both to think through a problem and weigh choices and to act once the choice is clear. Will is what enables us to overcome--to press through-inertia, anxiety, pride, or self-interest, to do what we know and feel is right. (Kagan, S. $(1992,16)$ ) Competence is also crucial. Good will alone will not ensure effective moral action. To solve a conflict fairly, for example, we need skills of listening, communicating our view, and finding a middle ground. To aid a person in distress, we need to be able to conceive and execute a plan of action. (Johnson, D.W., Johnson, R.T., and Smith, K.A., 1991,3) Found that children who had roleplayed a series of situations in which one child helped another were subsequently more likely than children without such experience to investigate a distress cry from another room. (McCann, J.E, Galbraith, J.R (1981,4). Report that "people who are capable of effective intervention and who feel competent to deal with emergencies are more likely than others to help". (Miller, L.K., Hamblin, R.L. (1963,5) These findings suggest that moral competence may benefit from a general feeling of effectiveness as well as specific skills. (Mitchell, T.R, Silver, W.S $(1991,6)$ Finally, moral action, in many situations, also benefits from habit. Believed that morally good actions arise from a steady state of character, a deeply rooted disposition to respond to situations in certain ways. People who have good character, "act truthfully, loyally, bravely, kindly, fairly without being much tempted by the opposite course" . Often they do not even think consciously about "the right choice." They are good by force of habit. (Mohr, L.B. (1971), 7) Habit begins in freedom, of course--with consciously made decisions to do the kind, courteous, or fair deed. An important part of our moral training, then, is developing good habits through repeated choices, habits that will serve us well not only when the going is easy but also when we are pressured, tired, or tempted. To recognize the role of habit in the moral life is to acknowledge what Aristotle argued: that virtue must be practiced, not merely known. (O’Leary-Kelly, A.M, Martocchio, J.J, Frink, D.D. (1994), 8) The implication of that principle is clear: Character education, wherever it occurs, must provide many and varied opportunities for young people to act--to live out their developing values and ideals, and to reflect on what they value in light of their lived moral experience. (9) The three components of moral agency--knowing, affect, and action--obviously do not always work together. We may think that we should give more money to charity or more time to our children, but not care enough to do so; we may feel we have wronged a colleague or subordinate but be too proud to apologize; we may be distressed about a deteriorating situation in our marriage but lack the imagination or will to effect an improvement. But in any situation, full moral agency involves a unity of knowing (whether conscious or not), affect, and action. CONCLUSION: Interdependence and Peace: Psychological Experimental Approach was the best result. Multicultural Education in positive Interdependence Psychology Perspective a interdependencel function was the best. It is essential that correlational evidence suggests that the way schools group eksperimen are run predicts the level of disorder they experience. Schools in group eksperimen which the administration and faculty communicate and work together to plan for change and solve problems have higher teacher morale and less disorder. These schools can presumably absorb change. Schools in which students notice clear school rules and reward structures and unambiguous sanctions also experience less disorder. These schools are likely to signal appropriate behavior for students. Schools in which students feel as though they belong and that people in the school care about them also experience less disorder. These schools are probably better at controlling behavior informally. Intervention studies have tested for a causal association between each of these factors and delinquency or substance use among students. Four major strategies for changing school and classroom environments in conflict area are summarized below: (1) building school capacity to manage itself; (2) setting norms or expectations for behavior and establishing and enforcing school rules, policies, or regulations; (3) changing classroom instructional and management practices to enhance classroom climate or improve educational processes; and (4) grouping students in different ways to achieve smaller, less alienating, or otherwise more suitable micro-climates within the school. 
Keywords: Psychological, peace, interdependence, performance, group

\section{INTRODUCTION}

Discusses the value of team and individual reward strategies and how these can be used to contribute to organisational change and success. A review of team effectiveness and models of teamwork are first discussed so that team rewards are understood as important motivators to accomplishing organisational objectives. Four factors need to be considered in establishing teambased rewards: the stages of a team life cycle, reward and recognition categories, the type of teams and the culture of the team and organisation. Forty-four specific reward tools are described which can be used for individual or team incentives. Comprehensive matrices are put forward which can be used to determine which tool should be used at which stage in a team's life cycle and with which type of team. Finally, the implementation cost, evaluation of team reward systems is considered.

A science of positive subjective experience, positive individual traits, and positive institutions promises to improve quality of life and prevent the pathologies that arise when life is barren and meaningless. (Johnson, D.W., and Johnson, R.T. (1984)). The exclusive focus on pathology that has dominated so much of our discipline results in a model of the human being lacking the positive features that make life worth living. Hope, wisdom, creativity, future mindedness, courage, spirituality, responsibility, and perseverance are ignored or explained as transformations of more authentic negative impulses. The 15 articles in this millennial issue of the American Psychologist discuss such issues as what enables happiness, the effects of autonomy and self-regulation, how optimism and hope affect health, what constitutes wisdom, and how talent and creativity come to fruition. The authors outline a framework for a science of positive psychology, point to gaps in our knowledge, and predict that the next century will see a science and profession that will come to understand and build the factors that allow individuals, communities, and societies to flourish.

"Positive interdependence is linking students together so one cannot succeed unless all group members succeed. (Johnson, D.W., and Johnson, R.T. (1984)). Group members have to know that they sink or swim together." "When students clearly understand positive interdependence, they understand that each group member's efforts are required and indispensable for group success and that each group member has a unique contribution to make to the joint effort because of his or her resources and/or role and task responsibilities" Positive goal interdependence ensures that the group is united around a common goal, a concrete reason for being, such as "learning the assigned material and making sure that all other members of your group learn the assigned material"

Three levels in establishing positive interdependence. The teacher first has to assign the group a clear, measurable task, then structure positive goal interdependence, and finally blend positive goal interdependence with other types of positive interdependence. There are nine types of positive interdependence

1. Positive Goal Interdependence: Students must realize that they can achieve their learning goals if, and only if, all the members of their group also achieve their goals.

2. Positive Celebration/Reward Interdependence: A mutual reward is given for successful group work and members' efforts to achieve it. (Ostroff, C (1993), 2)

3. Positive Resource Interdependence: Each member of the group has only a part of the information, resources, or materials necessary for his or her task. In this way, the members' resources have to be combined so that the group accomplishes its goal.

4. Positive Role Interdependence: Each member is assigned complementary and interconnected roles that show the responsibilities required by the group to fulfill a common task.

5. Positive Identity Interdependence: Group members have to find and agree upon a common identity, which can be a name, a motto, a slogan, a flag, or a song. 
6. Environmental Interdependence: Students are bound together by the physical environment in which they work. Thus, the teacher has to find an environment that unifies students.

7. Positive Fantasy Interdependence: The teacher gives students an imaginary task, for which they have to come up with solutions, for example a life-threatening situation or dealing with future technology. (Johnson, D.W., and Johnson, R.T. (1984))

8. Positive Task Interdependence: Work has to be organized sequentially. As soon as one team accomplishes its portion, the next team can proceed with its responsibility, and so on.

9. Positive Outside Enemy Interdependence: The teacher puts groups in competition with each other. In this way, group members feel interdependent and do their best to win the competition. (Pearce, J.L, Gregersen, H.B (1991), p.3)

10. Positive resource, role, and task interdependence result in individuals realizing that the performance of group members depends on the whole group and not on individuals. No student is on his/her own. As a result of mutual causation, cooperative efforts are characterized by positive inducibility in that group members are open to being influenced by each other. If one member of the group has taken an action, there is no need for other members to do so.

"Individual accountability is the measurement of whether or not each group member has achieved the groups' goal. Assessing the quality and quantity of each member's contributions and giving the results to all group members" Individual accountability is the factor that shows that students are learning better cooperatively. "The purpose of cooperative groups is to make each member a stronger individual in his or her own right". After participating in a cooperative lesson, group members should be better able to accomplish the same kind of tasks by themselves. They learn to do something together so that they can do it easier when they are alone. There are many ways to structure and increase individual accountability: by keeping the size of the groups small; by giving an individual test to each student; (Perrow, C. (1961),4) or by checking for understanding by giving random oral individual examinations. When students have to provide information in the presence of the group, the teacher can also structure individual accountability by observing each group and group member and by keeping track of students' contribution to the group's work. Individual accountability can be structured by assigning one student in each group to check for understanding. The checker poses questions, and the other group members provide rational answers supporting group answers. Students can also teach what they have learned to someone else or edit each other's work.

\section{PROBLEM}

Do Positive interdependence has numerous effects on individuals' motivation and productivity group multicultural, not the least of which is to highlight the fact that the efforts of all group members multicultural are needed for group success as a nation building?

\section{METHOD EXPERIMENTAL}

The basic assumption of this experiment is that instead of relying exclusively on the ingroupoutgroup distinction, individuals also base their perception of ingroups and outgroups on status differences between the groups. Accounts in terms of culture, attribution, and ideology, posit a general tendency for people to ascribe more homogeneity to the low-status than the high-status group. Motivational accounts, however, emphasize concrete behaviors and interactions between groups with unequal status. (Pilisuk,M. (2001),p.5). In particular, the subordination and outcome dependency conjectures predict that this discrepancy between subordinate and dominant homogeneities is moderated by the type and salience of the interaction between the high-status and the low-status groups. A very simple question then becomes: To what extent, and in which manner, 
does dominant-subordinates interaction contribute to the perception of variegated dominants and homogeneous subordinates?

The present study was designed to provide a preliminary answer to this question. It introduced a minimal procedure to create groups of unequal status, and used an indirect methodology to measure group homogeneity perceptions. (Pritchard, R.D, Jones, S.D., Roth, P.L, Stuebing, K.K, Ekeberg, S.E (1988,p.16).

Procedure and Design. The starting point for the elaboration of this experimental manipulation of. relative gratification and prejudice. (Rogness, J (1998),p.7). Beside social dominance theorists, numerous social psychologists have argued that stereotyping and prejudice help justify the economic and social superiority of those who have wealth and power for instance state that prejudice and discrimination "allow ingroup members to justify inequitable relationship with outgroups ". This conceptualization of prejudice as HE LM suggests that the fact of being privileged, of being invested in a high status position may trigger the need to justify such privileges, and consequently the tendency to denigrate others. In a first experiment designed in part to test such reasoning, we studied the effect of relative gratification on prejudice. Several studies have shown a link between relative deprivation and prejudice. Moreover, relative deprivation theorists have long argued that when the outcome of a comparison is positive, it results in relative gratification (RG), the opposite of RD. (Rogness, J (1998),5). Yet, no studies to our knowledge has ever sought to examine the relation between relative gratification and prejudice. If prejudice exists because it helps to rationalize or justify social and economic privileges, then putting individuals in a relatively privileged or gratified position ought to increase their level of prejudice. This hypothesis was tested and confirmed in an experiment involving studentsl. (Rogness, J (1998),6). We found that the level of prejudice of first-year psychology students is significantly higher when they are led to believe that job opportunities for psychology students are going to be extremely good in the near future, compared to when they are not provided with any information about their future social standing or when they are provided with information suggesting that their job outlook will be extremely poor. In other words, when students are put in a context where they expect to have access to a dominant social position, they become more hostile towards outgroups.( Rogness, J (1998)7)

The Status Variable. To introduce the aesthetic judgment task and set the stage for the status manipulation, the experimenter emphasized the concern of people to develop sensibility and personal tastes toward artistic works (paintings). These instructions brought into the fore the assumed shared norm of individual's autonomy, creativity, and distinctiveness. The experimenter then told the participants that they were going to examine paintings by a contemporary painter named "Sleek". It was emphasized that respected critics had praised some of these paintings while judging others to be of poor quality. (Rogness, J (1998),p.8). The experimenter told the participants that they would go over a booklet of reproductions of pairs of paintings, and that within each pair, one piece was considered to be of good quality and the other of poor quality. The participants' task would be to guess which one of the two pieces from each pair had been praised by the respected critics. . Following this task, the experimenter explained to the participants that on the basis of their performance, they would each be assigned to either the "Sleek" group (if they had succeeded on the task) or the "X" group (if they had not succeeded). The experimenter then explained that previous in-depth interviews with persons who had performed the same aesthetic task had allowed to assemble descriptions of the most typical members of the Sleek and $\mathrm{X}$ groups, which were distinguished by a gender-neutral nickname and were described by four traits (these traits were matched one with another according to their evaluation and content; thus, the content of the targets' descriptions did not bear any systematic link with the targets' group membership).

The participants formed impressions about these targets, and then completed a cued-recall task (a task that asked the participants to match the traits with the target people). They finally answered a questionnaire aimed at assessing how they perceived various aspects of the experimental situation 
(estimates of groups' prestige, numbers, etc.) (Rosenbaum, M.E, Moore, D.L, Cotton, J.L, Cook, M.S.,, Hieser, R.A., Shovar, M.N., Gray, M,J (1980),p.89).

\section{The intergroup relations variable.}

This experiment included a manipulation of the symbolic intergroup relationships. This symbolic relationship was induced by means of a task that the six target people which were presented to the participants had performed. In one condition, this task was ostensibly unrelated to the aesthetic competencies of the group members (i.e., to gather funds for humanitarian actions - non-relevance condition); in a second condition, the task was directly related to the aesthetic competencies (i.e., to organize an exposition of paintings - relevance condition); in a third condition, the instructions stressed that due to their intrinsic abilities, members of the Sleek group led the organization of this exposition, and members of the X group had played the role of assistants (relevance plus dominants' leading condition). (Rousseau, D.M (1977,p.110).

This variable was therefore aimed at manipulating the type (non-relevant vs. relevant) and the intensity (without dominants' leading vs. with dominants' leading) of the relationships between the dominant and the subordinate groups. If the discrepancy between dominant and subordinate homogeneity were mediated by motivational factors which accompany intergroup interaction, we should observe an increase in the discrepancy between the ascribed homogeneities starting from the non-relevance condition to the relevance plus dominants' leading condition. (Rousseau, D.M (1978,p111).

\section{FINDING: FINDING: EXPERIMENTAL OF PEACE}

1. Analysis of the data shows that the difference between the educational intentions of those interviewed in 1993 and 1999 is statistically significant. The average scale value of interviewees' intentions in 1993 was 2.02, while in 1999 it was 2.46.

\section{Fig. 1: Percentage of the intensity of the intention of interviewees to continue studying}

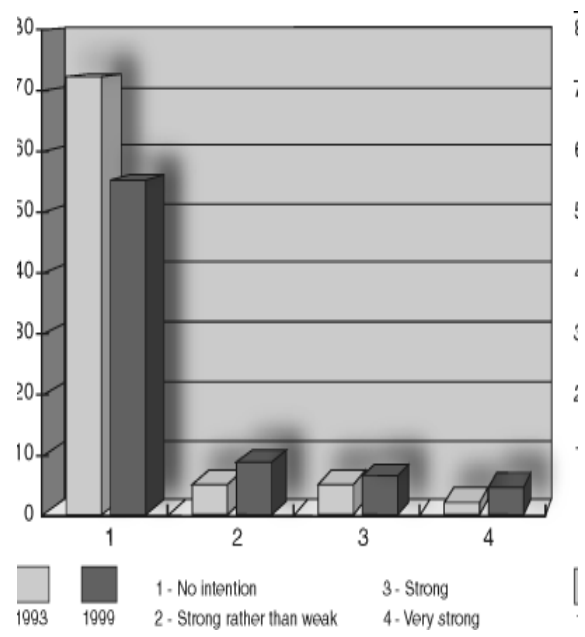


3. Much more significant is the difference in the educational aspirations of both groups of interviewees (Fig. 2). In 1993, 78.3\% of them expressed satisfaction with the level of education they had acquired, $5.2 \%$ wished to acquire secondary education, $2.9 \%$ college education, $9.1 \%$ university education, and $1 \%$ a higher degree. In 1999, the percentage of those satisfied with their education had decreased to $55.1 \%$, those wishing to gain a certificate of secondary education rose to $11.2 \%$, those wanting a college education fell to $2.9 \%$, those aspiring towards a university education rose to $20.5 \%$, and those aiming at a higher degree to $3.7 \%$. The analysis shows that the difference between the two studies in the educational aspirations of those interviewed is very significant, their average value in 1993 reaching 2.2, while in 1999 it reached 3.6.

Fig. 2: Percentage of interviewees wishing to acquire a higher level of education than they already have
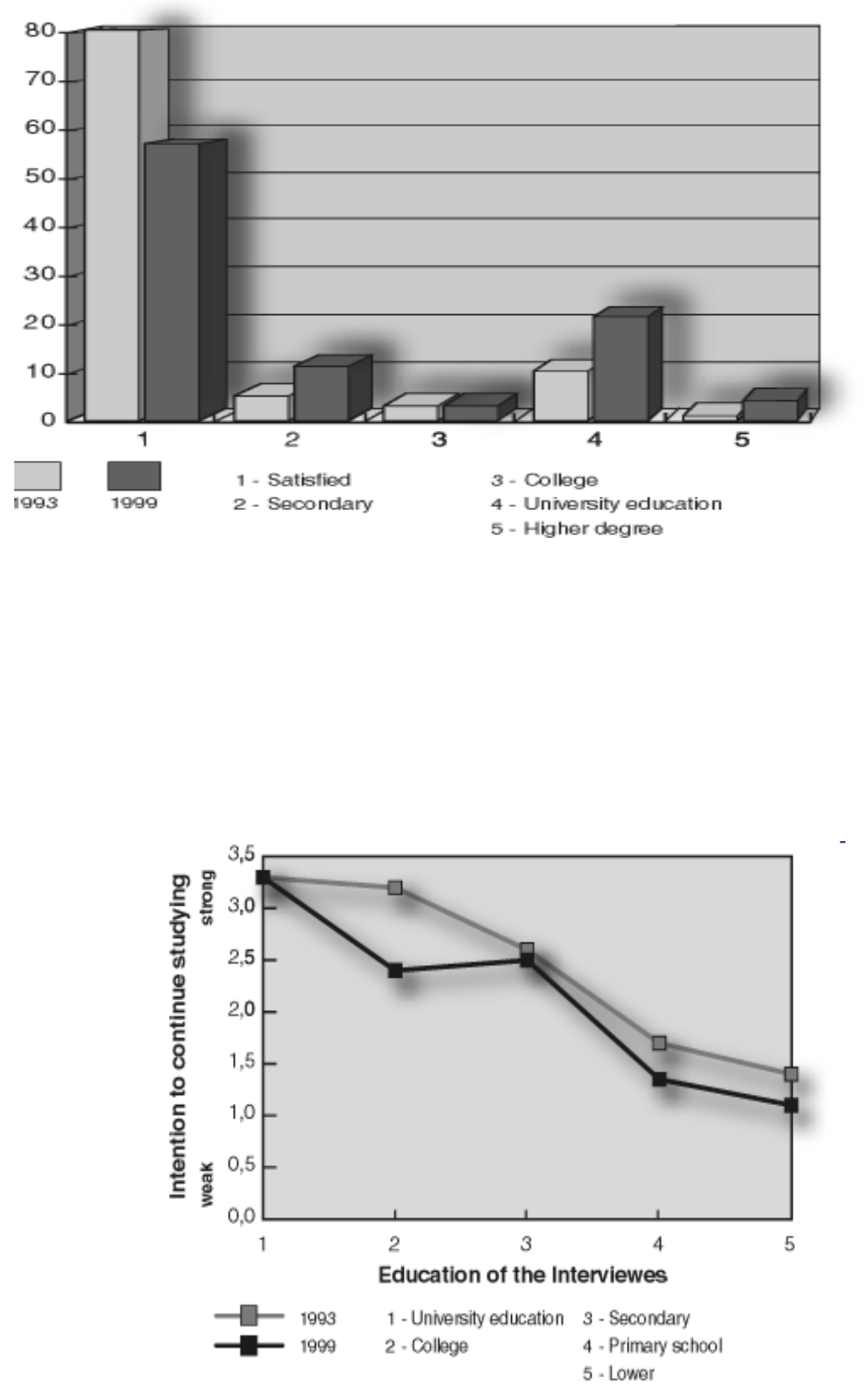

5. 


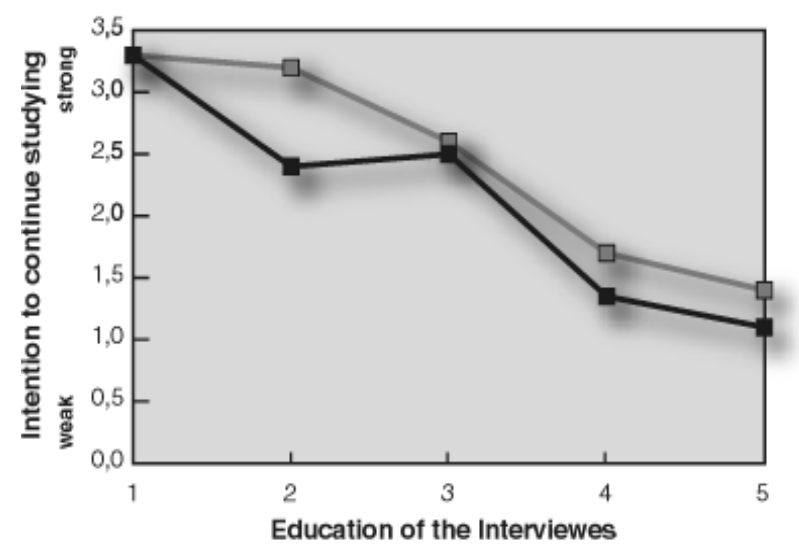

$\begin{array}{lll}-1993 & 1 \text { - University education } & 3 \text { - Secondary } \\ 1999 & \text { 2-College } & \text { 4-Primary school } \\ & & 5 \text { - Lower }\end{array}$

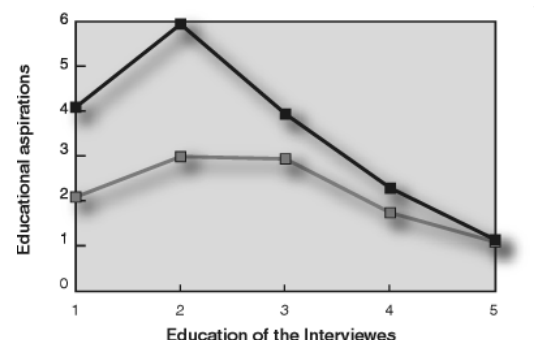

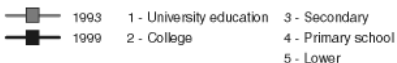




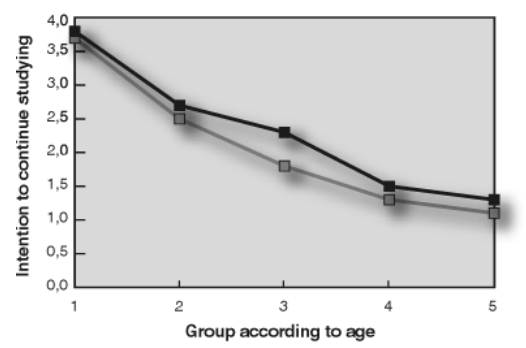

$\begin{array}{rrr}1993 & 1-18-30 & 3-41-50 \\ -1999 & 2-31-40 & 4-51-60 \\ & 5 \cdot \text { above } 6\end{array}$

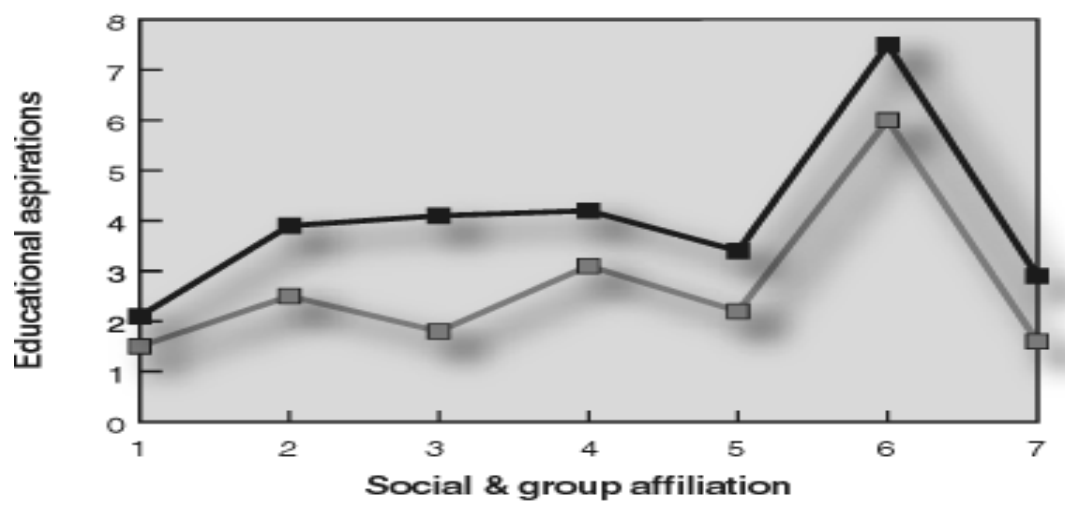

Social \& group affiliation

प- 1993 - Agriculture 5-Manual Workers

2 - Freelance 6 - Student

3 - Private sector 7 - Unemployed

4 - Non-manual workers 


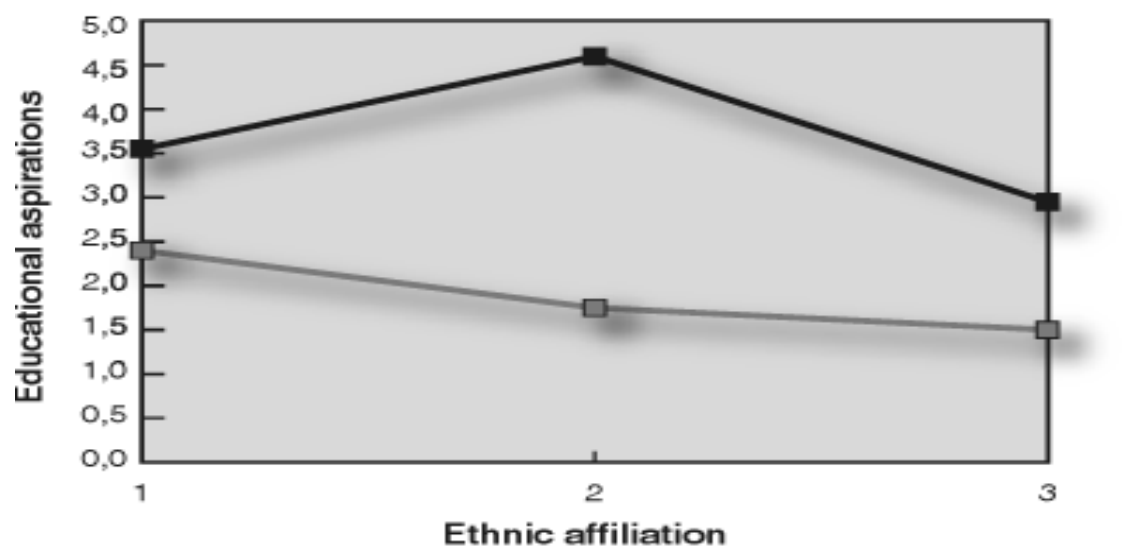

प $1993 \quad$ 1-Bulgarians 3 - Roma

2 - Bukgarian Turks

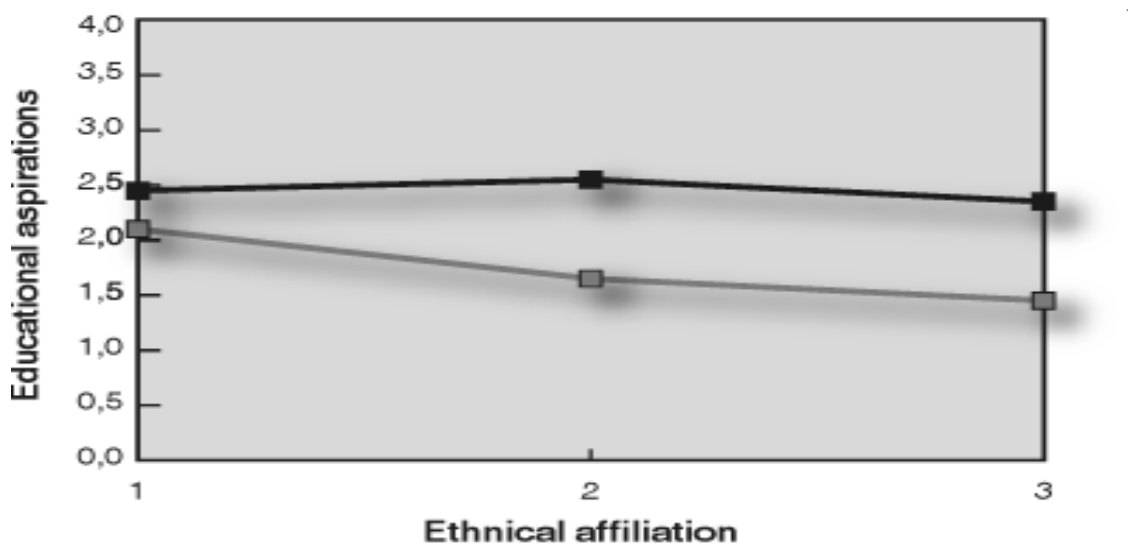

$\begin{array}{lll}1993 & 1 \text { - Bulgarians } & 3 \text { - Roma } \\ 1999 & 2 \text { - Bulgarian Turks }\end{array}$ 


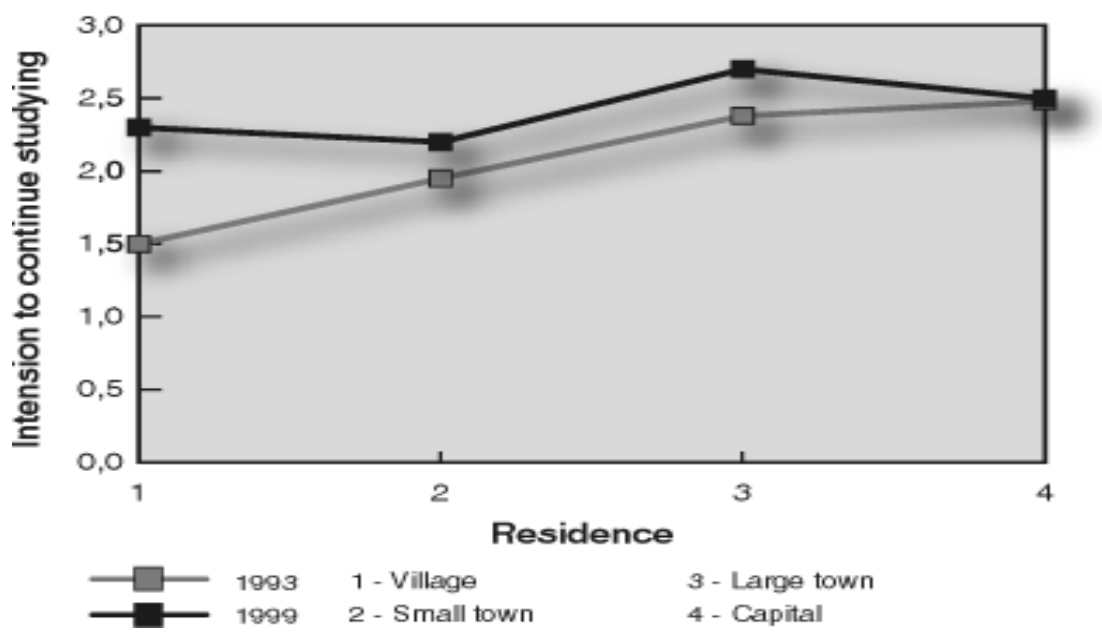

The goal of the present study is to examine workshops subyect in the post era with the aim of promoting reconciliation and peacebuilding between the sides. The workshops were organized, in the framework of a peace education. In these workshops, subject from pairs high schools met for two days to discuss social, cultural and political topics. Each workshop included approximately 10 youths from each side that were led jointly by a multiculture subject in group facilitator. The study examines four facets of these dialogue events, using both quantitative and qualitative research methods: (1) structure of activities and practices of transformative dialogue used in the encounter events; (2) attitudes and mutual stereotypes held by youth from both sides prior to the beginning of the workshops; (3) mutual perceptions and attitudes expressed by participants during the encounter; (4) effects of participation in the workshops on stereotypes held by the multiculture (comparisons).

To build peace, it was necessary to induce co-operation towards shared goals. A series of urgent problems was devised, which the subject could solve only by working together. They rejoiced together when the problem had been fixed.

In interpreting these results, one must be careful to note that no single experiment can establish by itself a principle of broad applicability. Furthermore, the conditions of Sherif's experiment differed markedly from the conflict-torn situations in the real world. The inescapable conclusion, however, is that co-operation on shared goals is of vital importance in resolving conflict peacefully. This conclusion has far-reaching implications for building a culture of peace. Simply stopping the fighting or bringing hostile groups together is not enough. Rather, co-operation must be nourished at diverse levels in the social system, building the sense of positive interdependence that lies at the heart of a culture of peace.

Each group would develop a very strong degree of trust and internal cohesion, while remaining flexible enough to have individual members leave and enter the group as needed. Norms would need to be established that all group members felt comfortable with (e.g., punctuality, level of direct expression of feelings, interpersonal conflict strategies, etc.). Agreed upon processes for resolving internal conflicts would need to be well developed and well practiced.

At the next level up, would be another group of 10 members. These mid-level groups would be comprised of the external co-leaders from 10 front-line groups. The purpose of this mid-level organization layer would be to achieve communication (horizontally and vertically) and coordination within the EXPERIMENT GROUP. Among this mid-level group of 10, there would be two designated co-coordinators, selected by the 10 mid-level group members. 
If there were more than 100 people deployed to a given situation, then the organizational structure could keep going up a level. For example, if there were 1000 people, there would be 100 front-line groups each with 10 members, and for each 10 groups there would be a mid- level group of 10, and above that, another group of 10 representatives of each of the mid-level groups. This would provide for effective communication from each volunteer to the central group as appropriate.

This entire structure in many ways resembles a military model -- e.g. strong discipline, tight organization, clear roles and protocols for decision-making and internal processes. However, it is different from a military model in many important ways. Nonviolence, of course, will be both a central value and practice -- but other values would be stressed, including a stronger investment in group harmony, some degree of democratic decision-making, and a diminishment of the polarization between the designated leaders and the regular volunteers.

Tasks and Decision Making: The in-group Coordinating Committee in a given conflict situation would have direct representation from the mid-level groups, direct connection with, and representation from, local peace organizations, and also have direct access headquarters, providing information exchange, support-needs identification, public education, etc.

Both the difficulty and the importance of effective intercultural communication issues cannot be underestimated. Creating such an organization within a culture would be a tremendous challenge -and trying to do this in an intercultural environment is an enormous undertaking. Prior to deployment, the group would have had extensive communication with the local peace and justice organizations, to identify the needs articulated and mechanisms for support, and would have developed a clear mandate for what the aimed to accomplish.

The relationship with the local peace organizations would be clear, and the goals of the mission would be transparent, quantifiable, and understood by all. The actual work of the experiment group would vary greatly from situation to situation, but would always be consistent with the mission.

Let me experiment with a hypothetical case study. In this example, I will explore how the EXPERIMENT GROUP could be useful in a "vertical" conflict (where there is an aggressor and, by most international perspectives, a "victim"). I wish to use the current conflict betweenexperiment group. As I am only minimally knowledgeable about this conflict, I shall make many assumptions in order to experiment with the peace team intervention idea -- and I hope my assumptions are neither too indicative of my ignorance, nor too unconsciously racist, imperialistic or ethnocentric. Let us also assume, for demonstration sake, that the conflict has dramatically escalated.

As mentioned above, I see this conflict as a vertical one. The geographically larger, more populous, better resourced and more armed country of Experiment group is demonstrating aggression towards Experiment group and is the provocateur of the conflict. I believe that Experiment group would have a different descrexperiment groupion -- but it appears that the general international consensus supports the gist of my assumptions.

If (for the moment anyway) we accept my assumptions, then we can consider the question of how an international peace team might effectively prevent and/or deter violence, war and aggression in this conflict.

In cooperation with, and support of, the local nonviolent peace and justice activists, and in this case with at least the tacit support of the Experiment group (by virtue of allowing the EXPERIMENT GROUP volunteers into the country), what if we were able to organize, fund and train 1,000 people into 100 different teams? What if we send 1,000 EXPERIMENT GROUP volunteers to Experiment group and place them along the boarder in small groups, in strategic places -- areas that Experiment group has been previously bombing? What would happen? 
Having the consent of the Experiment group would be very complicated. It would on the one hand be immensely useful, but clearly would destroy, or at least significantly diminish any possibility of nonpartisan status. But if this is a vertical conflict, and that is part of our analysis, than perhaps this is a logical consequence anyway. Certainly it is a dilemma worthy of thoughtful consideration, a dilemma that becomes further complicated if the Experiment group was bent on a military solution themselves.

At any rate, we now have 1000 volunteers in Experiment group, with the goal of making themselves human shields in designated villages, bridges, airports or other targeted areas. Welltrained, well equipped, well organized, and well funded -- what would happen next?

The EXPERIMENT GROUP Central Committee would have notified Experiment group of the arrival of the Peace Teams, and would have predetermined the location of each team and have shared those locations with the Experiment groupn Government. Experiment group would then have a strategic and moral dilemma. They would likely be furious at the EXPERIMENT GROUP for intervening in the conflict which heretofore had little international attention and which now would hopefully have significantly increased attention (reflecting the EXPERIMENT GROUP's media and Internet sophistication). But would they change their military strategy? Would they choose to bomb anyway and kill some of the internationals? Ignore their presence entirely? Back up and regroup? This is a central question for those of us placing hope in the EXPERIMENT GROUP being an effective peacekeeper and conflict transformer. Additionally, even if the EXPERIMENT GROUP stopped the immediate violence, how will the EXPERIMENT GROUP support long-term peacebuilding?

The probability of some of the volunteers being killed is high, either by mistake or by intention. This then must be a cause for which the volunteers are prepared to die. But we must remember the track record of previous attempts, and look critically at the data that exists, to see if the assumptions of deterrence and de-escalation and (relative) safety are correct.

I have a belief, buttressed by the work of previous peace teams, that there are sufficient numbers of people who are prepared to take such risks to promote peace. As part of an orchestrated intercultural coalition I would be willing to take such risks. But these risks would certainly bring up recruitment and retention issues.

Large questions remain to be addressed: How to interface with the local peace organizations and how to relate to ? This dilemma appears to be a delicate tightrope to walk, especially in horizontal conflicts (horizontal meaning conflicts where each side has relative equal power). What about the cultural issues? What would it mean to have an outside group intervene in a context where few people had much awareness of the cultural or the deeper implications of the conflict? Certainly part of the pre-deployment training would include a significant training on the culture(s) that will be encountered. (This is something the UN doesn't currently do for its peacekeepers!). Is this cultural imperialism? Perhaps in this case if the Movement invited the Peace Team members (or the Experiment group) it would be less complicated ... but what if there was no invitation? Would an international intervention be appropriate? What if the conflict was a horizontal one?

I believe that a nonviolent intervention, as opposed to an armed intervention (using the threat of force as its primary authority) would be a better choice -- largely because of my own belief and commitment to nonviolence, but also because I believe it would build a more lasting peace. When people stop fighting because someone with a larger weapon or larger numbers is telling them to stop, it is paternalistic and coercive. If people stop because they have been persuaded to stop, 
(perhaps still being "coerced" but using a very different type of coercion), I think their impetus to stop will be more solid, not necessarily a personal transformation, but at least compelled by a depth of analysis which goes deeper than through armed "persuasion." I also believe a nonviolent response will be cheaper -- both in loss of life and in dollars. Lastly, modeling nonviolence as a method to resolve and transform conflicts leaves a demonstration of something newer and more positive, whereas a military intervention leaves an impression that the biggest, strongest and most armed entity always prevails.

In the case study described above, having an international nonviolent intervention would have a significant effect. Group would have a much more difficult time waging this war if the eyes of the world were watching (and thus enduring the subsequent political consequences). The costs for such an intervention would be not so expensive. The largest cost would be the possible/probable loss of lives, and the training, travel and logistical support, which would be dramatically small compared to a military intervention. Am I correct in my assessment? Could we recruit volunteers to such an endeavor? Would anyone fund this kind of operation? There are so many questions -- yet such a strong pull to explore, create and innovate.

Clearly there is much for me to learn about the peace team concept and movement. What parts of my dreams are overly Western or problematically racist and patronizing? Is it reasonable to think that enough people would volunteer to put their lives on the line?

\section{DISCUSSION}

Due to time constraints, only the results concerning the cued-recall task will be reported here. From this task, we can compute measures of the extent to which the participants categorized the targets into groups, and homogenized their own group and the outgroup. Firstly, the results show the emergence of an unqualified categorization effect. They then demonstrate that the participants overall ascribed more homogeneity to the $\mathrm{X}$ group than to the Sleek group. This effect, however, is qualified by the participants' status and the intergroup relations variable. This interaction can be described as follows: (Saavedra, R, Earley, P.C, Van Dyne, L. (1993,p.12).

1) Among low-status people, the ingroup homogeneity effect increases linearly from the nonrelevance to the relevance plus dominants' leading condition. Notably, the results demonstrate an increase of the amount of ingroup homogeneity as well as of the amount of outgroup heterogeneity.

2) Among high-status people, we observe a different pattern of homogeneities. The dominants consistently homogenize the outgroup. However, this outgroup homogeneity effect fades when considering the progression from the non-relevance condition to the relevance plus dominants' leading condition. (Saavedra, R, Earley, P.C, Van Dyne, L. (1993,p.13).

3) Importantly, in the non-relevance condition, which represent the "default" situation from most of previous studies, we notice that low-status people homogenize the ingroup and the outgroup to a comparable extent, whereas the high-status people firmly homogenize their outgroup.

The sampling technique that was used in this research was multistage sampling. The questionnaires were administrated. The questionnaires were distributed through the first harvest during the season. All of the items after try out were valid. The real experiment were conducted in the second The subjects of the experiments were 402 in Pemerintah Kota Surabaya. The positive interdependence could improve peace group performance was the best, special in psychological perspective

How to do experiment research? The jigsaw classrom is very simple to use. If you're a teacher/experimental, just follow these steps (.Johnson, D.W., Johnson, R.T., and Smith, K.A., 1991) .( Saavedra, R, Earley, P.C, Van Dyne, L. $(1993,14)$

1.Divide students into 5- or 6-person jigsaw groups. The groups should be diverse in terms of gender, ethnicity, race, and ability.

2.Appoint one student from each group as the leader. Initially, this person should be the most mature student in the group. 
3.Divide the day's lesson into 5-6 segments. For example, if you want history students to learn about Eleanor Roosevelt, you might divide a short biography of her into stand-alone segments on: (1) Her childhood, (2) Her family life with Franklin and their children, (3) Her life after Franklin contracted polio, (4) Her work in the White House as First Lady, and (5) Her life and work after Franklin's death.

4.Assign each student to learn one segment, making sure students have direct access only to their own segment. (Saavedra, R, Earley, P.C, Van Dyne, L. (1993,p.15).

5.Give students time to read over their segment at least twice and become familiar with it. There is no need for them to memorize it.

6.Form temporary "expert groups" by having one student from each jigsaw group join other students assigned to the same segment. Give students in these expert groups time to discuss the main points of their segment and to rehearse the presentations they will make to their jigsaw group.

7.Bring the students back into their jigsaw groups.

8.Ask each student to present her or his segment to the group. Encourage others in the group to ask questions for clarification.

9.Float from group to group, observing the process. If any group is having trouble (e.g., a member is dominating or disruptive), make an appropriate intervention. Eventually, it's best for the group leader to handle this task. Leaders can be trained by whispering an instruction on how to intervene, until the leader gets the hang of it..

( Johnson, D.W., Johnson, R., and Smith, K. (1998).)

10.At the end of the session, give a quiz on the material so that students quickly come to realize that these sessions are not just fun and games but really count. (Saavedra, R, Earley, P.C, Van Dyne, L. (1993,p.16).

The jigsaw classroom is a cooperative learning technique with a three-decade track record of successfully reducing racial conflict and increasing positive educational outcomes. Just as in a jigsaw puzzle, each piece--each student's part--is essential for the completion and full understanding of the final product. If each student's part is essential, then each student is essential; and that is precisely what makes this strategy so effective. Here is how it works: The students in a history class, for example, are divided into small groups of five or six students each. Suppose their task is to learn about World War II. In one jigsaw group, Sara is responsible for researching Hitler's rise to power in pre-war Germany. Another member of the group, Steven, is assigned to cover concentration camps; Pedro is assigned Britain's role in the war; Melody is to research the contribution of the Soviet Union; Tyrone will handle Japan's entry into the war; Clara will read about the development of the atom bomb. Eventually each student will come back to her or his jigsaw group and will try to present a well-organized report to the group. The situation is specifically structured so that the only access any member has to the other five assignments is by listening closely to the report of the person reciting. Thus, if Tyrone doesn't like Pedro, or if he thinks Sara is a nerd and tunes her out or makes fun of her, he cannot possibly do well on the test that follows. (18). To increase the chances that each report will be accurate, the students doing the research do not immediately take it back to their jigsaw group. Instead, they meet first with students who have the identical assignment (one from each jigsaw group). For example, students assigned to the atom bomb topic meet as a team of specialists, gathering information, becoming experts on their topic, and rehearsing their presentations. We call this the "expert" group. It is particularly useful for students who might have initial difficulty learning or organizing their part of the assignment, for it allows them to hear and rehearse with other "experts." Once each presenter is up to speed, the jigsaw groups reconvene in their initial heterogeneous configuration. The atom bomb expert in each group teaches the other group members about the development of the atom bomb. Each student in each group educates the whole group about her or his specialty. Students are then tested on what they have learned about World War II from their fellow group member. What is the benefit of the jigsaw classroom? (Saavedra, R, Earley, P.C, Van Dyne, L. (1993.p.17). 
First and foremost, it is a remarkably efficient way to learn the material. But even more important, the jigsaw process encourages listening, engagement, and empathy by giving each member of the group an essential part to play in the academic activity. Group members must work together as a team to accomplish a common goal; each person depends on all the others. No student can succeed completely unless everyone works well together as a team. This "cooperation by design" facilitates interaction among all students in the class, leading them to value each other as contributors to their common task (Schmidt, K.H, Kleinbeck, U (1997,p.19).

Therefore, the Academies and other scientific institutions represented at this meeting reaffirm their commitment to the promotion of :

(1)- the awareness that science, as a product of the history and creativity of mankind, is an integral part of all cultures;

(2)- an increased effort in science education at all levels and in raising the young generations to be guided by a new vision of culture that embraces the scientific "ethos" and the spirit of free inquiry that characterizes science; (Schmidt, K.H, Kleinbeck, U (1997,p.120).

(3)- wider dissemination and better public understanding of science and technology;

(4)- balanced development of science and of technology, recognizing that both basic and applied sciences are vital for meeting human needs and for tackling problems such as hunger and disease, environmental degradation, rural and urban decline, and in the long run reducing disparities between rich and poor nations. International cooperation is a striking feature of the present century. Witnessing the dramatic trend of transition to new socio-economic structures, with the world in search of new goals and approaches, we strongly recommend that particular effort be focused on increasing the scientific and technological capabilities of developing countrie (Schmidt, K.H, Kleinbeck, U (1997,p.21).

\section{SUGESTION}

1. The jigsaw classroom was first used in 1971 in Austin, Texas. My graduate students and I had invented the jigsaw strategy that year, as a matter of absolute necessity to help defuse an explosive situation. The city's schools had recently been desegregated, and because Austin had always been racially segregated, white youngsters, African-American youngsters, and Hispanic youngsters found themselves in the same classrooms for the first time. Within a few weeks, long-standing suspicion, fear, and distrust between groups produced an atmosphere of turmoil and hostility. Fist-fights erupted in corridors and schoolyards across the city. The school superintendent called me in to see if we could do anything to help students get along with one another. After observing what was going on in classrooms for a few days, my students and I concluded that inter-group hostility was being fueled by the competitive environment of the classroom. Let me explain. In every classroom we observed, the students worked individually and competed against each other for grades. Here is a description of a typical fifth grade classroom that we observed The teacher stands in front of the class, asks a question, and waits for the children to signal that they know the answer. Most often, six to ten youngsters raise their hands, lifting themselves off their chairs and stretching their arms as high as they can in an effort to attract the teacher's attention. Several other students sit quietly with their eyes averted, hoping the teacher does not call on them. When the teacher calls on one of the eager students, there are looks of disappointment on the faces of the other students who had tried to get the teacher's attention. If the selected student comes up with the right answer, the teacher smiles, nods approvingly, and goes on to the next question. In the meantime, the students who didn't know the answer breathe a sigh of relief. They have escaped being humiliated this time. It took only a few days of observation and interviews for us to see what was going on in these classrooms. We realized that we needed to shift the emphasis from a relentlessly competitive atmosphere to a more cooperative one. (Schmidt, K.H, Kleinbeck, U (1997p.221). It was in this context that we invented the jigsaw strategy. Our first intervention was with fifth graders. First we helped several teachers devise a cooperative jigsaw structure for the students to learn about the life of Eleanor Roosevelt. We divided the students into small groups, diversified in terms of race, ethnicity and gender, 
making each student responsible for a specific part of Roosevelt's biography. Needless to say, at least one or two of the students in each group were already viewed as "losers" by their classmates. Carlos was one such student. Carlos was very shy and insecure in his new surroundings. English was his second language. He spoke it quite well, but with a slight accent. Try to imagine his experience: After attending an inadequately funded, substandard neighborhood school consisting entirely of Hispanic students like himself, he was suddenly bussed across town to the middle class area of the city and catapulted into a class with Anglo students who spoke English fluently, seemed to know much more than he did, and who were not reluctant to let him know it. When we restructured the classroom so that students were now working together in small groups, this was initially terrifying to Carlos. Now he could no longer slink down in his chair and hide in the back of the room. The jigsaw structure made it necessary for him to speak up when it was his turn to recite. Although he had gained a little confidence by rehearsing together with others who were also studying Eleanor Roosevelt's work with the United Nations, he was still reluctant to speak when it was his turn to teach the students in his jigsaw group. He blushed, stammered, and had difficulty covering the material he had learned. Skilled in the ways of the competitive classroom, the other students were quick to ridicule him. One of my research assistants heard some members of Carlos's group make comments such as, "You're stupid. You don't know what you're doing. You can't even speak English." Instead of admonishing them to "be nice" or "try to cooperate," she made one simple but powerful statement. It went something like this: "Talking like that to Carlos might be fun for you to do, but it's not going to help you learn anything about what Eleanor Roosevelt accomplished at the United Nations--and the exam will be given in about 15 minutes." In other words, she reminded the students that the situation had changed. The same behavior that might have been useful to them in the past, when they were competing against each other, was now going to cost them something very important: a chance to do well on the exam. Needless to say, old, dysfunctional habits do not die easily. But they do die. Within a few days of working with jigsaw, Carlos's group-mates gradually realized that they needed to change their tactics. It was no longer in their own best interest to rattle Carlos; they needed him to perform well in order to do well themselves. In effect, they had to put themselves in Carlos's shoes in order to find a way to ask questions that didn't undermine his performance. (Schmidt, K.H, Kleinbeck, U (1997.p.422).

After a week or two, most of Carlos's group-mates developed into skillful interviewers, asking him relevant questions and helping him articulate clear answers. And as Carlos succeeded, his groupmates began to see him in a more positive light. Moreover, Carlos saw himself in a new light, as a competent member of the class who could work with others from different ethnic groups. His selfesteem grew, and as it grew, his performance improved even more. In addition, Carlos began to see his group-mates as friendly and supportive. The ethnic stereoypes that the Anglo kids held about Carlos and that Carlos held about the Anglo kids were in the process of changing dramatically. School became a more humane, exciting place, and absenteeism declined. Within a few weeks, the success of the jigsaw was obvious. Teachers told us how pleased they were at the change in atmosphere. Visitors expressed amazement at the transformation. Needless to say, this was exciting to my graduate students and me. But as scientists, we needed more objective evidence--and we got it. Because we had randomly introduced the jigsaw intervention into some classrooms and not others, we were able to compare the progress of the jigsaw students with that of students in traditional classrooms. After only eight weeks there were clear differences, even though students spent only a small portion of their time in jigsaw groups. When tested objectively, jigsaw students expressed less prejudice and negative stereotyping, were more self-confident, and reported liking school better than children in traditional classrooms. Moreover, children in jigsaw classes were absent less often than were other students, and they showed greater academic improvement; poorer students in the jigsaw classroom scored significantly higher on objective exams than comparable students in traditional classes, while the good students continued to do as well as the good students in traditional classes. (Schmidt, K.H, Kleinbeck, U (1997,p.122).

2. Reducing Prejudice in the Classroom (.Johnson, R.T., Johnson, D.W., and Holubec, E.J. (1998)) 
Positive interdependence means that team members need each other to succeed. A childhood example is the three-legged race. Though smaller than the typical learning groups, it illustrates clearly the dependence each teammate has with the other individual. There are many forms of positive interdependence that can be structured in groups. One way learning goal interdependence can be ensured is if the group's goals include that all group members must understand a specific concept well enough to explain it to another group. Positive interdependence can be reached with product goal interdependence: i.e., when students must reach a consensus answer. A reward interdependence can be built into the group by having some form of shared grades. For example, besides their individual scores on an exam, students receive a certain number of points if all group members score at or above a certain grade. Resource interdependence relies on the fact that individuals each possess specific resources needed for the group as a whole to succeed. This can be arranged by giving specific resources to different individuals in the group. Role interdependence occurs when specific roles are assigned to group members, for example, recorder or time keeper. (23). The roles can rotate weekly to give all team members experience. Task interdependence occurs when one group member must first complete his/her task before the next task can be completed. For instance, collecting water samples might be assigned to two group member while research on how to collect samples is done by two other group members. One way to ensure that positive independence occurs lies with the face-to-face promotive interactions between group members. (Shea, G.P, Guzzo, R.A (1987), p.24).

3. One of the basic principles of cooperative learning is positive interdependence. But it is a concept often not fully understood. In our work with the concept, we distinguish two related components, each linked to one of the two words of the term, "positive" and "interdependence."

The "positive" of the term positive interdependence derives from research showing what happens when there is a positive correlation among outcomes. If when your outcomes go up, so too do mine, then there is a positive correlation among outcomes: Our outcomes go up or down together. Whenever we are in a situation in which there is a positive correlation among our outcomes, the probability of our cooperating is greatly enhanced. It is common sense: If I know your doing well will somehow help me, I will try to help you and I will encourage you to do well. Thus in situations in which there is a positive correlation among academic outcomes, students spontaneously tutor each other and encourage each other. We hear statements like, "Let me show you how to solve that kind of problem," and "I hope you do well on the quiz." To test for a positive correlation among outcomes, we ask, "Is a gain for one a gain for another?" or "Is my gain your gain?" he "interdependence" of the term positive interdependence describes not only the lack of independence among outcomes, but describes also situations of interdependence. In a situation in which either of us can accomplish a task on our own, in an important sense we are independent; we do not have to cooperate to reach our goal. On the other hand, in a situation in which we cannot accomplish the task unless we work together, in an important sense we are interdependent: we need to work together to reach our goal. To test for interdependence we ask, "Is help necessary?" Positive interdependence drives cooperation. If I know your doing well will help me, I work with you, helping and encouraging you. I feel myself to be on the same side with you. If I know I am in a situation in which I cannot maximize my outcomes working alone, if I know help is necessary, I seek and welcome cooperation and help. (Shea, G.P, Guzzo, R.A (1987), p.25).

Positive interdependence is an extraordinarily powerful concept. There are many ways to have students grasp the concept. One of my personal favorites is a kinesthetic approach: pair balance. I have students in pairs face each other and extend their arms straight toward each other until their palms meet. Then I have them gradually take tiny steps backward. They are to do this until they reach a position in which both would fall if the other let go. While in this position, I have them discuss the concept of positive interdependence. Does one leaning forward help the other to obtain the balance point? Could they do the pair balance alone? The students grasp the concept of positive interdependence through their kinesthetic intelligence.

Another way to have students understand the concept is to have them think about the cells of their own body. Could the heart muscles pump without oxygen? Could the blood cells deliver oxygen 
without the lungs and diaphragm? But would the diaphragm move to inflate the lungs if it did not receive signals from the brain? Could any of the cells function for any length of time if it were not for the digestive system? Any one organ system doing well helps the others and none could function without the help of the others. (Shea, G.P, Guzzo, R.A (1987), p.3)

Yet another way for students to see the concept of positive interdependence is to think of a baseball team. When the team wins, is it because of the fielding, the pitching, the batting, or the coaching?

4. Animal behavior provides wonderful and often mysterious examples of positive interdependence. Most of us are familiar with examples from insects and mammals: Bees communicating to each other the location of a new find; ants teaming up to fertilize and tend an underground mushroom garden; wolves working together to bring down an animal much larger than any one of them. What gave me pause was Attenborough's description of interdependence among single cell organisms. Single cells group to form organized colonies; working together they accomplish what separately they cannot. One remarkable example of positive interdependence at the microscopic level is the Volvox, a hollow sphere, almost the size of a pinhead. The Volvox consists of a large number of cells, each with a flagellum. The striking thing about the cells of the Volvox is that they are virtually the same as other single cells that swim by themselves and have separate existences. The constituent cells of Volvox, however, are coordinated, for all the flagella around the sphere beat in an organized way and drive the tiny ball in a particular direction Attenborough's description of common sponges provides an even more spectacular and mysterious example of positive interdependence. Some thousand million years ago sponges took their place in the evolutionary line-up. Sponges take various forms, some as large as two meters. Sponges feed by filtering particles from a stream of water passing through their bodies. The water is drawn in through the coordinated beating of flagella: food is filtered out, and the water is expelled through vents. The amazing thing is that the whole sponge is a colony; members of the colony are relatively free, and individual cells sometimes crawl about the surface of the sponge. More amazing is that if the sponge is forced through a sieve so the individual cells are separated, with time they reorganize themselves into a sponge again, with each type of cell finding its appropriate place in the organism! Even more remarkable: If the cells of two sponges are all separated and then mixed together, they come together to form one large sponge, with each type of cell finding its appropriate place in the colony! Cooperation among single cell organisms! With roots that deep, can we doubt that it is natural for us to organize ourselves into groups in which each person contributes his or her unique talents? (Shea, G.P, Guzzo, R.A (1987), p.8)

5. Recently Laurie went to a seminar in which participants filled in a single information form. In telling me about the seminar, she suggested we create a similar form for participants at our workshops. Immediately I was in favor of the idea because for some time we have been multiplying the number of different participant forms at our events $\tilde{N}$ one to sign up for the online newsletter, another to request catalogs, a third to tell us how they heard about the workshop, and yet another to request future workshops. The idea of one form was very appealing, easier on participants and easier on the presenter.

The idea seemed simple enough. (Kagan, S. (1992),p.23). I drafted a form incorporating the items from the separate forms, and then sent it out for feedback to those who would be using the form. Brian, our information technologist (computer guru) let me know that if I made a few changes, he could program the computer so it would automatically send information needed by different people to them via E-mail so we would not need to print carbonless copy forms. Nancy, our director of professional development, needed a change in the questions so we could better tell which of her marketing techniques were working. Laurie realized that if this new, integrated form was to be used with all participants at Kagan events, it would have to be revised to account for the fact that some participants attend events required by their districts while others attend events they have selected. Liz, who sets up consulting events and a past model teacher, caught some grammar errors. I 
reworded questions with an eye on readability issues. Jeanne, who does accounting and workshop registration, has a great eye for spelling and caught several errors which slipped by everyone else. Karen, our graphic designer, needed to change the form to have it compliment the "look and feel" of Kagan publications. Mike, our office manager, wanted some changes so the flow of information would be smoother when the forms returned to the office. After all those changes had been incorporated, Laurie pretested the form at a workshop she was giving, and we discovered that participants filled in parts of the form in ways none of us had anticipated, necessitating yet another revision! What I thought would be a simple task turned out to be enormously multi-faceted. As I got feedback from different sources, I was amazed. The input was almost non-overlapping. Everyone viewed the form from their own perspective. Each one improved the form in a different way. What better example of positive interdependence could we have? No one person can look at anything from all points of view. For us to do the best possible job at anything, we work in a team, respecting the contributions of each team member. The gains of one are the gains of another; no one person can do alone that which the individuals working as a team can accomplish. Thus the pet phrases of cooperative learning have their roots in the concept of positive interdependence: Four heads are better than one. None of us is as smart as all of us. Cooperative Learning is Learning... to the Fourth Power. (Sheppard, J.A (1993.p86)

6. a successful teaching strategy in which small teams, each with students of different levels of ability, use a variety of learning activities to improve their understanding of a subject. Each member of a team is responsible not only for learning what is taught but also for helping teammates learn, thus creating an atmosphere of achievement. Students work through the assignment until all group members successfully understand and complete it. Cooperative efforts result in participants striving for mutual benefit so that all group members: gain from each other's efforts. (Your success benefits me and my success benefits you.) recognize that all group members share a common fate. (We all sink or swim together here.) know that one's performance is mutually caused by oneself and one's team members. (We can not do it without you.) feel proud and jointly celebrate when a group member is recognized for achievement. Slocum, J.W, Sims, H (1980.p.7) (We all congratulate you on your accomplishment!).

7. Why use Cooperative Learning? Research has shown that cooperative learning techniques:, promote student learning and academic achievement, increase student retention, enhance, student satisfaction with their learning experience, help students develop skills in oral communication, develop students' social skills, promote student self-esteem, help to promote positive race relations

5 Elements of learning, less prejudice. It is only under certain conditions that cooperative efforts may be expected to be more productive than competitive and individualistic efforts. Those conditions are:

\subsection{Positive Interdependence (sink or swim together))}

Each group member's efforts are required and indispensable for group success

Each group member has a unique contribution to make to the joint effort because of his or her resources and/or role and task responsibilities

5.2. Face-to-Face Interaction (promote each other's success)

Orally explaining how to solve problems

Teaching one's knowledge to other

Checking for understanding

Discussing concepts being learned

Connecting present with past learning

\subsection{Individual \& Group Accountability ( no hitchhiking! no social loafing)}

Keeping the size of the group small. The smaller the size of the group, the greater the individual accountability may be.

Giving an individual test to each student.

Randomly examining students orally by calling on one student to present his or her group's work to 
the teacher (in the presence of the group) or to the entire class.

Observing each group and recording the frequency with which each member-contributes to the group's work. Slocum, J.W, Sims, H (1980.p.6)

Assigning one student in each group the role of checker. The checker asks other group members to explain the reasoning and rationale underlying group answers.

Having students teach what they learned to someone else.

5.4. Interpersonal \& Small-Group Skills Social skills must be taught: Leadership Decision making Trust-building Communication Conflict-management skills

\subsection{Group Processing}

Group members discuss how well they are achieving their goals and maintaining effective working relationships Describe what member actions are helpful and not helpful.Make decisions about what behaviors to continue or change (Susman, G. (1976.p.8)

\section{REFERENCES}

.Johnson, D.W., and Johnson, R.T. (1984). Circles of Learning. Washington, DC: Assoc. supervision and Curriculum Dev.

.Johnson, D.W., Johnson, R.T., and Smith, K.A., 1991. "Cooperative learning: increasing college faculty instructional productivity," ASHE-ERIC Higher Education Rept. 4. Washington, D.C. [Online]. Available from the World Wide Web: http://www.ntlf.com/html/lib/bib/922dig.htm. [Cited 2004-02-24]

.Johnson, D.W., Johnson, R., and Smith, K. (1998). Active Learning: Cooperation in the College Classroom. Edina, MN: Interaction Book Co.

.Johnson, R.T., Johnson, D.W., and Holubec, E.J. (1998). Cooperation in the Classroom. Boston: Allyn and Bacon.

Kagan, S. (1992). Cooperative Learning. San Juan Capistrano, CA: Resources for Teachers, Inc. .Available from the World Wide Web: http://clte.asu.edu/active/preparing.htm. [Cited 2004-0526]

McCann, J.E, Galbraith, J.R (1981), "Interdepartmental relations", in Nystrom, P, Starbuck, W (Eds),Handbook of Organizational Design, Oxford University Press, New York, NY,, Vol. 2 pp.60-84.

Miller, L.K., Hamblin, R.L. (1963), "Interdependence, differential rewarding, and productivity", American Sociological Review, Vol. 28, pp.768-77..

Mitchell, T.R, Silver, W.S (1991), "Individual and group goals when workers are interdependent: effects on task strategy and performance'", Journal of Applied Psychology, Vol. 75 pp.18593..

Mohr, L.B. (1971), "Organization technology and organization structure", Administrative Science Quarterly, Vol. 16 pp.444-59.

O’Leary-Kelly, A.M, Martocchio, J.J, Frink, D.D. (1994), "A review of the influence of group goals on group performance", Academy of Management Review, Vol. 3 No.7, pp.1285-1301.

Ostroff, C (1993), "The relationship between satisfaction, attitudes, and performance: an organizational level analysis", Journal of Applied Psychology, Vol. 77 pp.963-74.

Pearce, J.L, Gregersen, H.B (1991), "Task interdependence and extra role behavior: a test of the mediating effects of felt responsibility", Journal of Applied Psychology, Vol. 76 pp.838-44.

Perrow, C. (1961), "The analysis of goals in complex organizations", American Sociological Review, Vol. 26 pp.854-65.

Pilisuk,M. (2001)," Ecological Psychology, Caring, and the Boundaries of the Person ", Journal of Humanistic Psychology, Vol. 41, No. 2, 25-37 DOI: 10.1177/0022167801412004 (c) 2001 SAGE Publications

Pritchard, R.D, Jones, S.D.,, Roth, P.L, Stuebing, K.K, Ekeberg, S.E (1988), "Effects of group feedback, goal setting, and incentives on organizational productivity", Journal of Applied Psychology, Vol. 73 pp.337-58. 
Rogness, J (1998), "Are cooperative goals necessary for constructive conflict processes?", Applied Psychology: An International Review, .

Rosenbaum, M.E, Moore, D.L, Cotton, J.L, Cook, M.S.,, Hieser, R.A., Shovar, M.N., Gray, M,J (1980), "Group productivity and process: pure and mixed reward structures and task interdependence", Journal of Personality and Social Psychology, Vol. 39 pp.626-42.

Rousseau, D.M (1977), "Technological differences in job characteristics, employee satisfaction, and motivation: a synthesis of job design and sociotechnical theory", Organizational Behavior and Human Performance, Vol. 19 pp.18-42.

Rousseau, D.M (1978), "Characteristics of departments, positions, and individuals: contexts for attitudes and behavior", Administrative Science Quarterly, Vol. 23 pp.521-40.

Saavedra, R, Earley, P.C, Van Dyne, L. (1993), "Complex interdependence in task performing groups", Journal of Applied Psychology, Vol. 78 pp.61-72.

Schmidt, K.H, Kleinbeck, U (1997), "Relationships between group-based performance measures, feedback and organizational contexts factors", European Journal of Work and Organizational Psychology, Vol. 6 pp.303-21.

Shea, G.P, Guzzo, R.A (1987), "Groups as human resources", in Ferris, G.R., Rowland, K.M (Eds), Research in Personnel and Human Resources Management, JAI Press, Greenwich, CT, Vol. 5 pp.323-56.

Sheppard, J.A (1993), "Productivity loss in performance groups: a motivation analysis", Psychological Bulletin, Vol. 113 pp.67-81.

Slocum, J.W, Sims, H (1980), "A typology for integrating technology, organization, and job design", Human Relations, Vol. 33 pp.193-212.

Susman, G. (1976), Autonomy at Work: A Sociotechnical Analysis of Participative Management, Praeger, New York, NY. 